\title{
Analysis of bulk density on heterogeneous sandy and silty clay deposition in deltaic environment
}

\begin{abstract}
This paper monitors the variation of bulk density in predominant sandy and silty clay soil in deltaic environment. The behavior of this geotechnical property expresses the degree of soil compaction at different depth of these two formation, monitoring and evaluation was carried through experimental investigations at different location at $5 \mathrm{~m}$ deep, the results generated values that express fluctuation from graphical representation, these were between shallow depth of five meters deep, the fluctuation of these values from these ten location show the refection of soil heterogeneity in the deltaic environment. The application of these results can be applied in geotechnical or highway design and construction of flexible pavement.
\end{abstract}

Volume I Issue 4 - 2017

Eluozo SN, Uzoh UE

Department of Civil Engineering College of Engineering,

Gregory University Uturu, Nigeria

Correspondence: Eluozo SN, Department of Civil Engineering College of Engineering, Gregory University Uturu, Nigeria, Email Soloeluozo2013@hotmail.com

Received: July 25, 2017 | Published: December 15, 2017

Keywords: analysis, bulk density, heterogeneous sand, silty clay

\section{Introduction}

The accuracy of soil water content measurement using timedomain reflectometry (TDR) depends on:

a. The accuracy of time delay measurement.

b. The calibration used to convert measured time delay to volumetric soil water content.

Many techniques have been developed to improve the accuracy of time delay measurement. For example, the switching diode technique has been employed to obtain an unambiguous time mark in the Moisture Point TDR soil moisture instrument. ${ }^{1-6}$ Meanwhile, several calibration equations have been developed to explore the relationship between time delay and volumetric soil water ${ }^{7-13}$ developed a wellknown 'Universal' empirical calibration equation between apparent dielectric permittivity $\mathrm{Ka}$ and volumetric water content $\mathrm{v}$. This universal calibration has been validated by numerous reports for two decades, when it is applied to general soil conditions. However, with the increase of resolution and accuracy of time delay measurement a discrepancy between ${ }^{7-9}$ universal calibration and experimental results has been reported when the universal relationship of Kaversus was applied to soil with high clay content and salinity. ${ }^{14-18}$ The apparent dielectric constant $\mathrm{Ka}$ of a material is determined by measuring the propagating time (time delay) of an electromagnetic (EM) wave in that material. ${ }^{19-24}$ In practice, an EM wave is sent through the material of interest along a transmission line (probe) buried in it (Table 1), and the EM wave is reflected back at the end of the transmission line. The round-trip time T is then measured. According to Maxwell's equation (Table 2), the velocity $\mathrm{v}$ of an EM wave propagating in a material medium with apparent dielectric permittivity Ka can be calculated. ${ }^{25-29}$

Table I Bulk density of the soil at different depth

\begin{tabular}{ll}
\hline Depth meter $(\mathrm{mm})$ & Bulk density $1000 \mathrm{~kg} / \mathrm{m}^{3}$ \\
\hline 0.2 & 2.54 \\
0.4 & 2.52 \\
0.8 & 2.54 \\
\hline
\end{tabular}

\begin{tabular}{ll} 
Table Continued.. & \\
\hline Depth meter $(\mathbf{m m})$ & Bulk density $1000 \mathrm{~kg} / \mathrm{m}^{3}$ \\
\hline $\mathrm{I}$ & 2.58 \\
1.2 & 2.61 \\
1.4 & 2.61 \\
1.6 & 2.61 \\
1.8 & 2.62 \\
2 & 2.64 \\
2.5 & 2.66 \\
3 & 2.7 \\
4 & 2.68 \\
5 & 2.68 \\
\hline
\end{tabular}

Table 2 Bulk density of the soil at different depth

\begin{tabular}{ll}
\hline Depth meter $(\mathbf{m m})$ & Bulk density $1000 \mathrm{~kg} / \mathrm{m}^{3}$ \\
\hline 0.2 & 2.5 \\
0.4 & 2.53 \\
0.8 & 2.54 \\
1 & 2.56 \\
1.2 & 2.57 \\
1.4 & 2.62 \\
1.6 & 2.65 \\
1.8 & 2.68 \\
2 & 2.74 \\
2.5 & 2.67 \\
3 & 2.72 \\
4 & 2.62 \\
5 & 2.63 \\
\hline
\end{tabular}




\section{Materials and method}

Natural sample of sandy and silty clay was obtained manually from various locations at a depth of about 1-5m (Table 3 ). The collected and manufactured soil was subjected to laboratory tests in order to determine its base on of the geotechnical properties (Table 4). The test conducted was bulk density, the standard application of determining bulk density was carried out. These tests were conducted based on B.S 1377-1990 (Table 5).

Table 3 Bulk density of the soil at different depth

\begin{tabular}{ll}
\hline Depth meter $(\mathbf{m m})$ & Bulk density $1000 \mathrm{~kg} / \mathbf{m}^{3}$ \\
\hline 0.2 & 2.52 \\
0.4 & 2.53 \\
0.8 & 2.53 \\
1 & 2.55 \\
1.2 & 2.56 \\
1.4 & 2.57 \\
1.6 & 2.59 \\
1.8 & 2.6 \\
2 & 2.6 \\
2.5 & 2.61 \\
3 & 2.62 \\
4 & 2.63 \\
5 & 2.64 \\
\hline
\end{tabular}

Table 4 Bulk density of the soil at different depth

\begin{tabular}{ll}
\hline Depth meter $(\mathrm{mm})$ & Bulk density $1000 \mathrm{~kg} / \mathrm{m}^{3}$ \\
\hline 0.2 & 2.71 \\
0.4 & 2.7 \\
0.8 & 2.68 \\
1 & 2.66 \\
1.2 & 2.57 \\
1.4 & 2.58 \\
1.6 & 2.1 \\
1.8 & 2.11 \\
2 & 2.11 \\
2.5 & 2.62 \\
3 & 2.63 \\
4 & 2.64 \\
5 & 2.65 \\
\hline
\end{tabular}

Table 5 Bulk density of the soil at different depth

\begin{tabular}{ll}
\hline Depth meter $(\mathbf{m m})$ & Bulk density $1000 \mathrm{~kg} / \mathrm{m}^{3}$ \\
\hline 0.2 & $2.5 \mathrm{I}$ \\
0.4 & 2.5 \\
\hline
\end{tabular}

\begin{tabular}{ll} 
Table Continued.. & \\
\hline Depth meter $(\mathbf{m m})$ & Bulk density $1000 \mathrm{~kg} / \mathbf{m}^{3}$ \\
\hline 0.8 & 2.52 \\
$\mathrm{I}$ & 2.52 \\
1.2 & 2.53 \\
1.4 & 2.55 \\
1.6 & 2.56 \\
1.8 & 2.57 \\
2 & 2.54 \\
2.5 & 2.54 \\
3 & 2.54 \\
4 & 2.63 \\
5 & 2.64 \\
\hline
\end{tabular}

\section{Results and discussion}

Results and discussion are presented in tables including graphical representation for bulk Density stated below (Table 6). The study has express thoroughly the behavior of soil in terms of bulk density; ${ }^{30-32}$ such characteristic was investigated to determine various (Table 7) degree of soil compaction at different lithology, Figure 1 developed vacillation from $1-5 \mathrm{~m}$ were the optimum bulk density were observed at $3 \mathrm{~m}$ and constantly maintain linear bulk density between $4-5 \mathrm{~m}$. Figure 2 developed oscillation but the optimum values was recorded at $2.5 \mathrm{~m}$ and suddenly observed slight decrease in fluctuation form between 3-5m. (Figure 3) developed fluctuations between $1.1 .5 \mathrm{~m}$ thus experiences sudden increase between 2 and $3 \mathrm{~m}$ and gradually increase to the optimum level at $5 \mathrm{~m}$. Figure 4 experienced sudden decrease (Table 8 ) and finally maintained linear increase between $3-5 \mathrm{~m}$. Figure 5 express vacillation between $1-5 \mathrm{~m}$, but developed optimum values recorded at $5 \mathrm{~m}$. Figure 6 in similar condition developed fluctuation where the optimum values were recorded at $3.5 \mathrm{~m}$ and suddenly vacillate again between $4-5 \mathrm{~m}$. (Figure 7) maintained similar condition by fluctuation from $1-5 \mathrm{~m}$ (Table 9) where the optimum values were recorded at $5 \mathrm{~m}$. (Figure 8) experienced slight vacillation between $1-2 \mathrm{~m}$ and suddenly increase to optimum level recorded at $5 \mathrm{~m}$. (Figure 9) observed sudden increase between $1-1.5 \mathrm{~m}$ (Table 10) and suddenly decrease with increase in depth, the developed gradual increase between $3-5 \mathrm{~m}$. (Figure 10) developed fluctuation from 1-5m and experience the optimum values recorded at $5 \mathrm{~m}$.

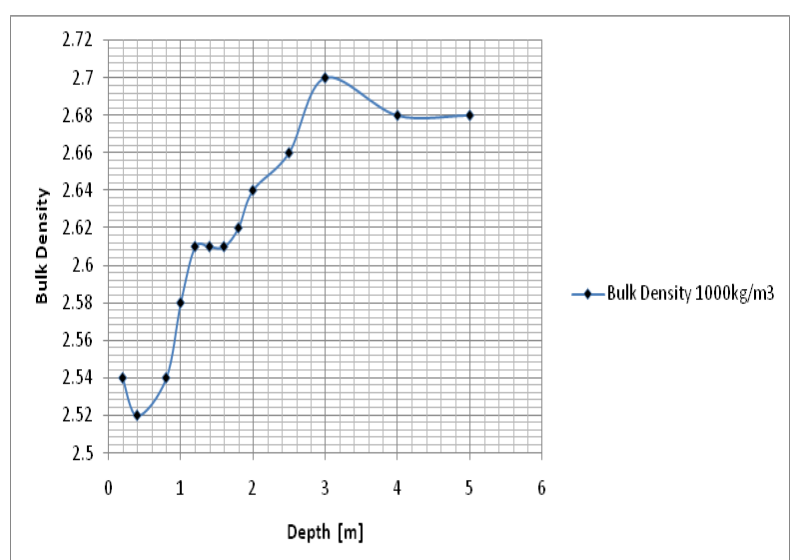

Figure I Bulk density of the soil at different depth. 
Table 6 Bulk density of the soil at different depth

\begin{tabular}{ll}
\hline Depth meter $(\mathrm{mm})$ & Bulk density $1000 \mathrm{Kg} / \mathrm{m}^{3}$ \\
\hline 0.2 & 2.54 \\
0.4 & 2.52 \\
0.8 & 2.54 \\
$\mathrm{I}$ & 2.58 \\
$\mathrm{I} .2$ & $2.6 \mathrm{I}$ \\
$\mathrm{I} .4$ & $2.6 \mathrm{I}$ \\
$\mathrm{I} .6$ & $2.6 \mathrm{I}$ \\
$\mathrm{I} .8$ & 2.62 \\
2 & 2.64 \\
2.5 & 2.66 \\
3 & 2.73 \\
4 & 2.68 \\
5 & 2.68 \\
\hline
\end{tabular}

Table 7 Bulk density of the soil at different depth

\begin{tabular}{ll}
\hline Depth meter $(\mathbf{m m})$ & Bulk density $1000 \mathrm{Kg} / \mathrm{m}^{3}$ \\
\hline 0.2 & 2.5 \\
0.4 & $2.5 \mathrm{I}$ \\
0.8 & 2.54 \\
$\mathrm{I}$ & 2.56 \\
1.2 & 2.57 \\
1.4 & 2.61 \\
1.6 & 2.57 \\
1.8 & 2.55 \\
2 & 2.61 \\
2.5 & 2.67 \\
3 & 2.69 \\
4 & 2.65 \\
5 & 2.71 \\
\hline
\end{tabular}

Table 8 Bulk density of the soil at different depth

\begin{tabular}{ll}
\hline Depth meter $(\mathrm{mm})$ & Bulk density $1000 \mathrm{Kg} / \mathrm{m}^{3}$ \\
\hline 0.2 & 2.52 \\
0.4 & 2.53 \\
0.8 & 2.53 \\
$\mathrm{I}$ & 2.55 \\
1.2 & 2.56 \\
1.4 & 2.57 \\
1.6 & 2.59 \\
1.8 & 2.6 \\
2 & 2.6
\end{tabular}

\begin{tabular}{ll}
2.5 & 2.61 \\
3 & 2.62 \\
4 & 2.63 \\
5 & 2.64 \\
\hline
\end{tabular}

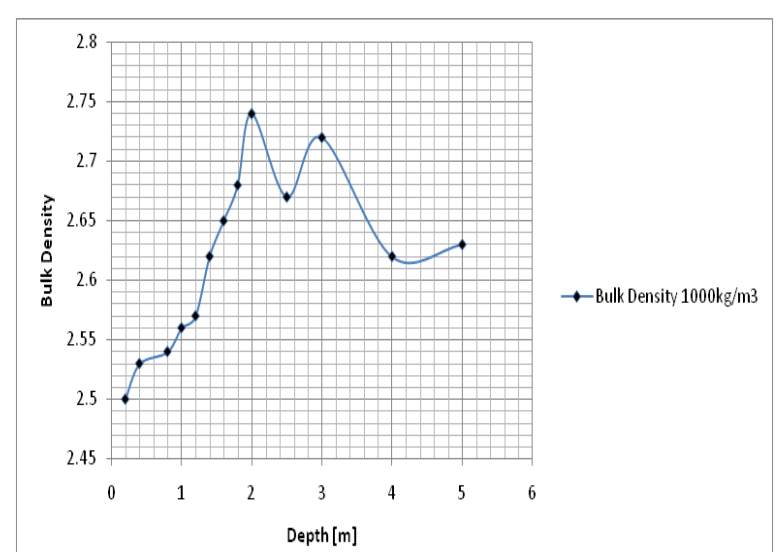

Figure 2 Bulk density of the soil at different depth.

Table 9 Bulk density of the soil at different depth

\begin{tabular}{ll}
\hline Depth meter $(\mathbf{m m})$ & Bulk density $1000 \mathrm{Kg} / \mathrm{m}^{3}$ \\
\hline 0.2 & $2.7 \mathrm{I}$ \\
0.4 & 2.7 \\
0.8 & 2.68 \\
$\mathrm{I}$ & 2.66 \\
$\mathrm{I} .2$ & $2.6 \mathrm{I}$ \\
$\mathrm{I} .4$ & 2.58 \\
$\mathrm{I} .6$ & 2.6 \\
$\mathrm{I} .8$ & $2.6 \mathrm{I}$ \\
2 & $2.6 \mathrm{I}$ \\
2.5 & 2.62 \\
3 & 2.63 \\
4 & 2.64 \\
5 & 2.65 \\
\hline
\end{tabular}

Table I 0 Bulk density of the soil at different depth

\begin{tabular}{ll}
\hline Depth meter $(\mathbf{m m})$ & Bulk density $1000 \mathrm{Kg} / \mathrm{m}^{3}$ \\
\hline 0.2 & $2.5 \mathrm{I}$ \\
0.4 & 2.5 \\
0.8 & 2.52 \\
$\mathrm{I}$ & 2.52 \\
$\mathrm{I} .2$ & 2.53 \\
$\mathrm{I} .4$ & 2.55 \\
$\mathrm{I} .6$ & 2.55 \\
$\mathrm{I} .8$ & 2.56 \\
2 & 2.57 \\
\hline
\end{tabular}


Table Continued.

\begin{tabular}{ll} 
Depth meter $(\mathbf{m m})$ & Bulk density $1000 \mathrm{Kg} / \mathbf{m}^{3}$ \\
\hline 2.5 & 2.54 \\
3 & 2.54 \\
4 & 2.54 \\
5 & 2.58 \\
\hline
\end{tabular}

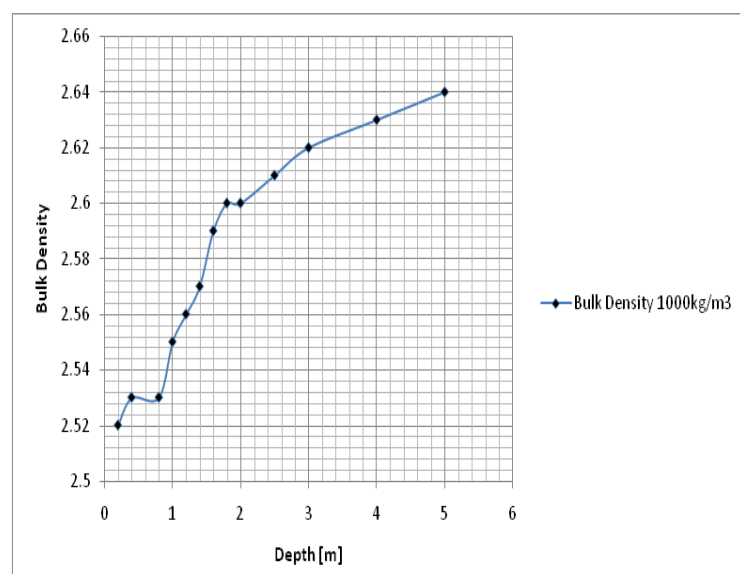

Figure 3 Bulk density of the soil at different depth.

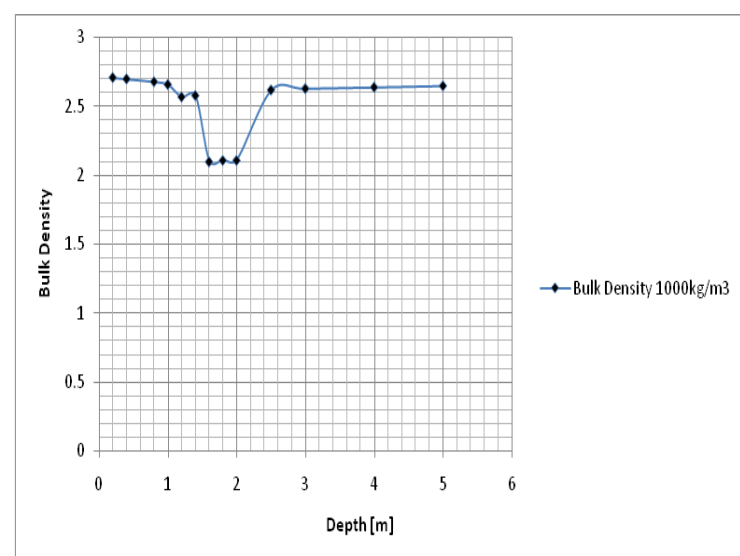

Figure 4 Bulk density of the soil at different depth.

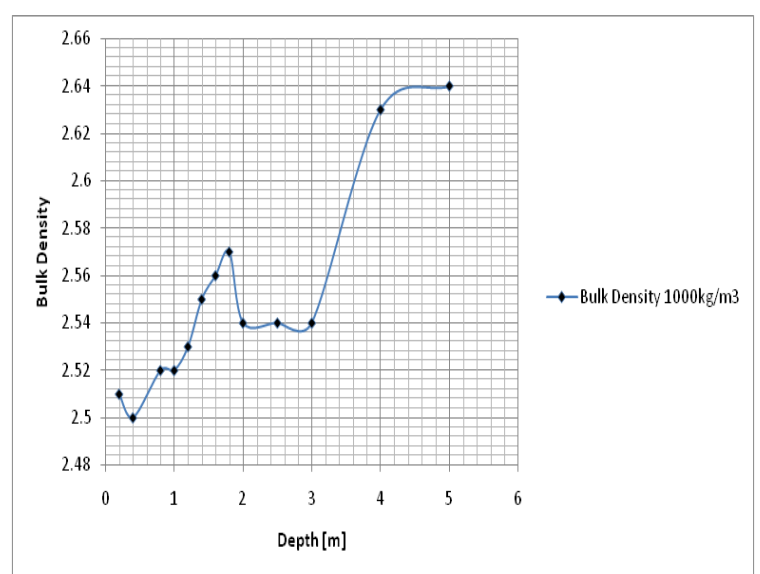

Figure 5 Bulk density of the soil at different depth.

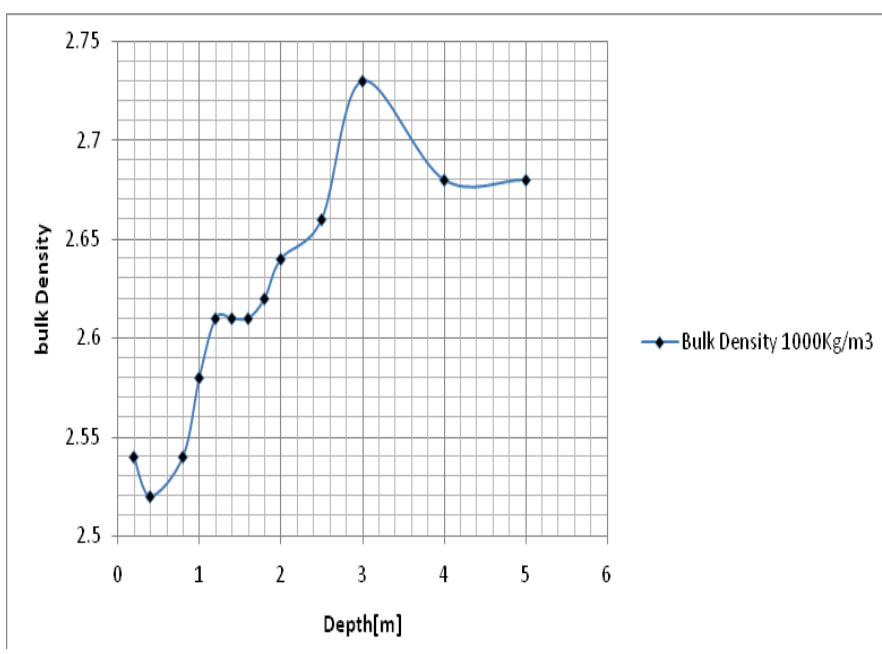

Figure 6 Bulk density of the soil at different depth.

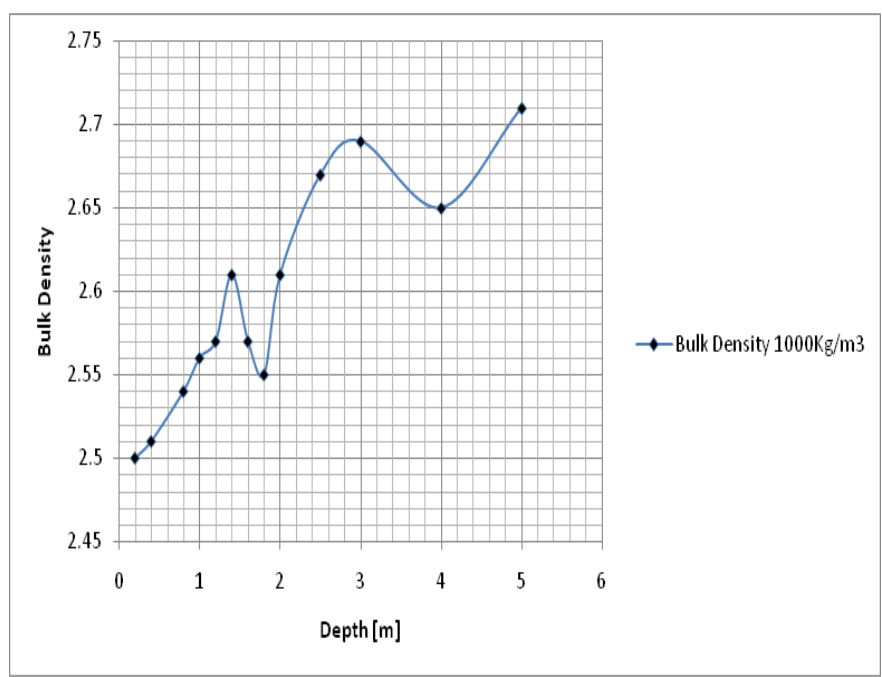

Figure 7 Bulk density of the soil at different depth.

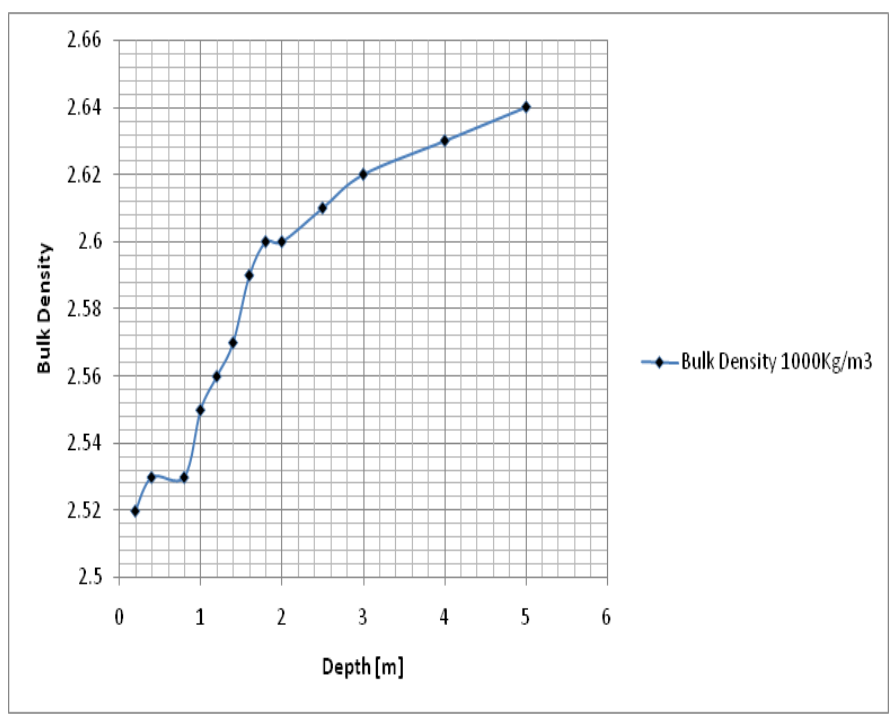

Figure 8 Bulk density of the soil at different depth. 


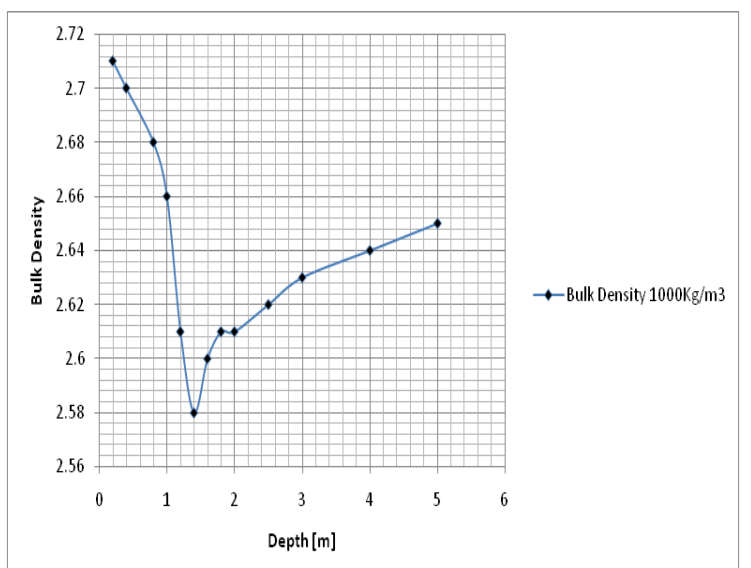

Figure 9 Bulk density of the soil at different depth.

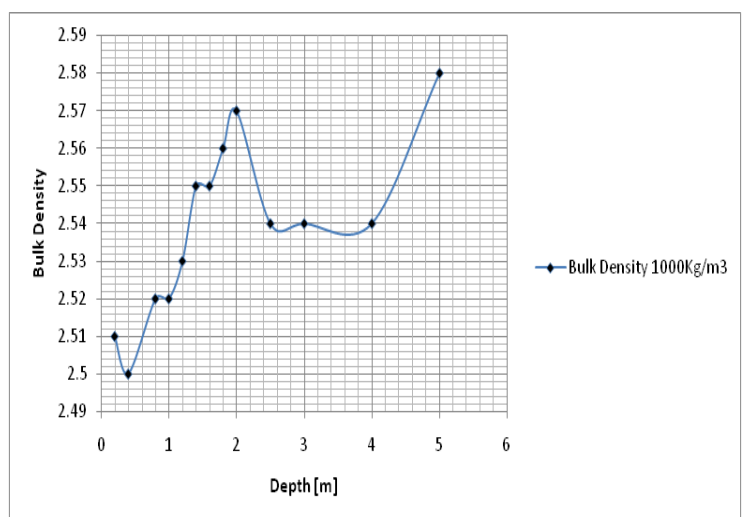

Figure 10 Bulk density of the soil at different depth.

\section{Conclusion}

The study has thorough express the variation in the formation at the deltaic environment, the predominance of deltaic deposition developed heterogeneity on bulk density of the soil, the deposition of the soil are predominantly influenced by the rate of density at different depth, this was done to determine bulk density of sandy and silty clay, it normally done for thorough geotechnical or high way purpose, base on these geotechnical properties of compaction, bulk density are thoroughly analyzed, monitoring the degree of compaction, is imperative for these two purpose due to the variation of bulk density within these predominant formation in deltaic environment. It also including its rate of compaction that has been expressed, the results will be applied for thorough engineering design and construction for geotechnical and high way road design.

\section{Acknowledgements}

None.

\section{Conflict of interest}

The author declares no conflict of interest.

\section{References}

1. Dalton FN. Development of time domain reflectometry for measuring soil water content and bulk soil electrical conductivity. In Advances in Measurement of Soil Physical. 1992:143-167.
2. Properties: Bring Theory into Practice. In: Topp GC, editor. USA: Soil Science Society of America, Special Publication 30; p. 143-167.

3. Dirksen C, Dasberg SI. Improved calibration of time domain reflectometry soil water content measurements. Soil Science Society of America Journal. 1993;57(3):660-667.

4. Ferr'e PA, Knight JH, Rudolph DL, et al. Spatial averaging of water content by time domain reflectometry: implications for twin rod probes with and without dielectric coatings. Water Resources Research. 1996;32(2):271-280.

5. Ferr'e PA, Rudolph DL, Kachanoski RG. A numerically based analysis of the sensitivity of conventional and alternative time domain reflectometry probes. Water Resources Research. 2000;36(9):2461-2468.

6. Herkelrath WN, Hamburg SP, Murphy F. Automatic real-time monitoring of soil moisture in a remote field area with time domain reflectometry. Water Resources Research. 1991;27(5):857-864.

7. Hilhorst MA, Dirksen C, Kampers FWH, et al. Dielectric relaxation of bound water versus soil matric pressure. Soil Science Society of America Journal. 2001;65(2):311-314.

8. Hook WR, Livingston NJ. Errors in converting time domain reflectometry measurements of propagation velocity to estimates of soil water content. Soil Science Society of America Journal. 1996;59:35-41.

9. Hook WR, Livingston NJ, Sun ZJ, et al. Remote diode shorting improves measurement soil water by time domain reflectometry. Soil Science Society of America Journal. 1992;56(5):1383-1391.

10. Jacobsen $\mathrm{OH}$, Schjonning P. A laboratory calibration of time domain reflectometry for soil water measurement including effects of bulk density and texture. Journal of Hydrology. 1993;151(2-4):147-157.

11. Jordan EC. In Reference Data for Engineers: Radio, Electronic, Computer, and Communications. 7th ed. USA: Howard W Sam \& Company; 1989. p. 4-23.

12. Knight JH, Ferr'e PA, Rudolph DL, et al. A numerical analysis of the effects of coatings and gaps upon relative dielectric permittivity measurement with time domain reflectometry. Water Resources Research. 1997;33(6):1455-1460.

13. Ledieu J, De Ridder P, Dautrebande S. A method of measuring soil moisture by time-domain reflectometry. Journal of Hydrology. 1986;88(34):319-328.

14. Malicki MA, Walczak RT, Koch S, et al. Determining soil salinity from simultaneous readings of its electrical conductivity and permittivity using $T D R$. In Symposium and Workshop on Time Domain Reflectometry in Environmental, Infrastructure, and Mining Applications, United States Department of Interior Bureau of Mines. 1994. p. 328-336.

15. Malicki MA, Plagge R, Roth $\mathrm{CH}$. Improving the calibration of dielectric TDR soil moisture determination taking into account the solid soil. European Journal of Soil Science. 1996;47(3):357-366.

16. Nadler A, Dasberg S, Lapid I. Time domain reflectometry measurement of water content and electrical conductivity of layered soil columns. Soil Science Society of America Journal. 1991;55:938-943.

17. Or D, Wraith JM. Temperature effects on soil bulk dielectric permittivity measured by time domain reflectometry: a physical model. Water Resources Research. 1999;35(2):371-383.

18. Pepin S, Livingston NJ, Hook WR. Temperature dependent on measurement errors in time domain reflectometry determinations of soil water. Soil Science Society of America Journal. 1995;59:38-43.

19. Rhoades JD, Manteghi NA, Shouse PJ, et al. Soil electrical conductivity and soil salinity: new formulations and calibrations. Soil Science Society of America Journal. 1989;53(2):433-439. 
20. Roth K, Schulin R, Fluhler H, et al. Calibration of time domain reflectometry for water content measurement using a composite dielectric approach. Water Resources Research. 1990;26(10):2267-2273.

21. Sun ZJ, Young GD. Saline clayey soil moisture measurement using time domain reflectometry. In TDR 2001: The Second International Symposium and Workshop on Time-Domain Reflectometry for Innovative Geotechnical Applications. USA: North Western University; 2001.

22. Sun ZJ, Young GD, McFarlane R, et al. The effect of soil electrical conductivity on moisture determination using time domain- reflectometry in sandy soil. Canadian Journal of Soil Science. 2000;80(1):13-22.

23. Topp GC, Davis JL, Annan AP. Electromagnetic determination of soil water content: measurements in coaxial transmission lines. Water Resources Research. 1980;16(3):574-582.

24. Topp GC, Davis JL, Annan AP. Electromagnetic determination of soil water content using TDR: I. Applications to wetting fronts and steep gradients. Soil Science Society of America Journal. 1982;46:672-684.

25. Topp GC, Zeglin S, White I. Impacts of real and imaginary components of relative permittivity on time domain reflectometry measurements in soil. Soil Science Society of America Journal. 2000;64(4):1244-1252.

26. Handbook of Physics and Chemistry. In: Weast RC, editor. 67th ed. Florida: CRC Press; 1986.
27. Whalley WR. Considerations on the use of time-domain reflectometry (TDR) for measuring soil water content. Journal of Soil Science. 1993;44(1):1-9.

28. White I, Zegelin SJ, Topp GC, et al. Effect of bulk electrical conductivity on TDR measurement of water content in porous media. In Symposium and Workshop on Time Domain Reflectometry in Environmental, Infrastructure, and Mining Applications, United States Department of Interior Bureau of Mines. 1994. p. 294-308.

29. Wraith JM, Or D. Temperature effects on soil bulk dielectric permittivity measured by time domain reflectometry: experimental evidence and hypothesis development. Water Resources Research. 1999;35(2):361-369.

30. Wyseure GCL, Mojid MA, Malik MA. Measurement of volumetric water content by TDR in saline soils. European Journal of Soil Science. 1997;48(2):347-354.

31. Young MH, Fleming JB, Wierenga PJ, et al. Rapid laboratory of time domain reflectometry using upward infiltration. Soil Science Society of America Journal. 1997;61:707-712.

32. Yuanshi G, Qiaohong C, Zongjia S. The effects of soil bulk density, clay content and temperature on soil water content measurement using time-domain reflectometry hydrological processes. Hydrol Process. 2003; 17:3601-3614. 